\title{
Desecration of Corpses in Relation to $\S 8(1)$ no. 9 German Code of Crimes Against International Law (VStGB): The Judgment of the German Federal Court of Justice (Bundesgerichtshof) of July 27, 2017-3 StR 57/17
}

\author{
Vanessa Bergmann ${ }^{1, \star}$, Franziska Blenk ${ }^{2, * *}$ and Nathalie Cojger ${ }^{3, * * *}$ \\ ${ }^{1}$ Legal Clerkship, Higher Regional Court, Nuremberg, Germany, ${ }^{2}$ Legal Clerkship, Higher Regional Court, Munich, Germany \\ and ${ }^{3}$ Friedrich-Alexander-University Erlangen-Nürnberg, Nürnberg, Germany \\ Corresponding author: Vanessa Bergmann, Email: bergmann.vanessa@outlook.de
}

(Received 28 November 2019; revised 02 August 2020; accepted 08 February 2021)

\begin{abstract}
As a reaction to the killing and beheading of two soldiers in the Syrian Civil War, the German Federal Court of Justice (BGH) set a milestone in the interpretation of $\$ 8(1)$ no. 9 of the German Code of Crimes against International Law (VStGB). The judges confirmed the conviction of a young German citizen with Syrian roots, Aria L., who had been tried and convicted before the Higher Regional Court of Frankfurt am Main (Oberlandesgericht (OLG) Frankfurt am Main). Within the certiorari, the BGH reviewed whether the statute conformed with the principle of legality found within the Grundgesetz (GG), Germany's constitution. The Court held that the corpse of a person killed is protected from desecration under humanitarian law pursuant to $\$ 8(1)$ no. 9 VStGB, the equivalent to Article 8(2)(b)(xxi) and (3)(ii) of the Rome Statute for the International Criminal Court (ICC). Reviewing this particular decision, it was determined that under the circumstances of a noninternational armed conflict, beheading someone, placing the head on a metal rod, and taking pictures afterward in order to upload them onto social media is gravely humiliating and degrading. The head is incomparably the part of the body that identifies a person. Furthermore, it is irrelevant whether the perpetrator had any physical influence over the person. In addition, war crimes can be committed in a non-international conflict, which should, however, be treated equally as an international conflict. This outcome triggered diverse reactions amongst legal scholars, especially due to the extension of the understanding of a "person" who is to be protected under humanitarian law.
\end{abstract}

Keywords: International criminal law; desecration of corpses; German criminal law; war crimes; Syrian Civil War; humanitarian law; person to be protected under international humanitarian law

${ }^{\star}$ Vanessa Bergmann acquired a graduate degree in German Law in July 2019 and currently conducts a legal clerkship at the Higher Regional Court in Nuremberg, Germany.

${ }^{* *}$ Franziska Blenk acquired a graduate degree in German Law in July 2019 and currently conducts a legal clerkship at the Higher Regional Court in Munich, Germany.

${ }^{* * *}$ Nathalie Cojger acquired a graduate degree in German Law in July 2019 and is currently a research associate for the Chair of Prof. Dr. Christoph Safferling and the Chair of Prof. Dr. Hans Kudlich at the Friedrich-Alexander-University ErlangenNürnberg, Germany.

The authors wish to thank Dr. Kevin Pike and Prof. Dr. Christoph Safferling for providing them with the opportunity to write this contribution to the German Law Journal and for their support throughout. 


\section{A. Introduction}

The mutilation and desecration of corpses has long been a component of psychological warfare, especially in the Syrian and Iraqi wars. Social media platforms have been abused to spread sensitive content, particularly pictures and videos demonstrating cruel and heinous acts. This method of distribution is utilized to intimidate opponents and to recruit new terrorist soldiers. Specifically, these social media platforms appeal primarily to young people. Therefore, carrying out such acts is an effective way of beguiling fascinated young men in an attempt to induce them to participate in wars. By gaining respect amongst like-minded individuals for posting brutal content online, this strategy successfully encourages more people to do the same. As a consequence, Germany recognized its obligation to become involved and react to such acts by prosecuting them properly and effectively.

As of April 23, 2020, the German Federal Prosecutor's Office (Bundesstaatsanwaltschaft) has evaluated more than eighty International Criminal Proceedings cases. ${ }^{1}$ As a reaction to the increasing cruelty of the conflicts in Syria and Iraq, Germany's Federal Prosecutor's Office has dealt with $\$ 8(1)$ no. $9 \mathrm{VStGB}^{2}$ - war crimes against persons-on three separate occasions. ${ }^{3} \mathrm{~A}$ novel ruling by the Third Criminal Senate of the $\mathrm{BGH},{ }^{4}$ referring to the decision of the OLG ${ }^{5}$ Frankfurt am Main, interprets international criminal law pursuant to $₫ 8(1)$ no. 9 VStGB in a German context. ${ }^{6}$ This raises the key question in this decision as to whether deceased persons can be deemed protected persons under international humanitarian law within the meaning of $\$ 8(1)$ no. 9 VStGB and, at the same time, reveals the challenges of an interpretation in conformity with international law.

\section{B. Circumstances of the Decision}

In order to entirely comprehend this decision to its fullest extent, it is imperative to take a look at the circumstances. Therefore, the legal developments concerning the prosecution of crimes in the context of international criminal law within Germany will be dealt with in the following section, in addition to outlining the facts of the case. 4

\section{Legal Development Within Germany}

Germany has dealt with the increasing number of terrorist acts by invoking several additional sections to its Criminal Code (StGB), ${ }^{7}$ for example, $\$ 129 \mathrm{a}$ - forming terrorist organizations ${ }^{8}$ — or the recently introduced $\$ 89 \mathrm{a}$ - preparation of serious violent offenses endangering the state. ${ }^{9}$ However,

\footnotetext{
${ }^{1}$ Markus Sehl, Ein Weltstrafverfahren in Koblenz, Legal Tribunal Online (Apr. 23, 2020).

${ }^{2}$ VÖlKerstrafgesetzbuch [VStGB] [InTERnational Criminal Code], $₫ 8$.

${ }^{3}$ See Bundesgerichtshof [BGH] [Federal Court of Justice] Sept. 8, 2016, Neue JuRISTISCHE WochensCHRIFT [NJW] 3604, para. 22, 2016 (Ger.); Kammergericht [KG] [Higher Regional Court of Berlin], Case No. (2A) 172 OJs 26/16 (3/16), para. 51, (Mar. 1, 2017).

${ }^{4}$ The court system of Germany consists of five branches of law: The ordinary courts, the administrative courts, the financial courts, the labor courts, and the social courts. The ordinary jurisdiction, mainly dealing with criminal and civil cases, administers the law in four instances: Magistrates' courts (Amtsgericht), district courts (Landgericht), higher regional courts (Oberlandesgericht), and the Federal Court of Justice (BGH), based in Karlsruhe. The BGH, as a court of last resort, only deals with cases as a matter of law.

${ }^{5}$ Oberlandesgericht [OLG] [Higher Regional Court].

${ }^{6}$ Bundesgerichtshof [BGH] [Federal Court of Justice] July 27, 2017, NEUE JURISTISCHE WOCHENZEITSCHRIFT [NJW] 3667 (2017) (Ger.) [hereinafter Judgment of July 27, 2017].

${ }^{7}$ See Strafgesetzbuch [STGB] [German CRiminal Code], translation at http://www.gesetze-im-internet.de/englisch stgb/index.html (Ger.) [hereinafter STGB].

${ }^{8} I d$.

${ }^{9}$ Id. For further information, see Christopher Ohnesorge, Julia Wilkes, Marius Eichfelder, Jinnus Rastegar, Matthias Derra \& Julia Balmer, The Constitutionality of $\$ 89$ a of the German Criminal Code (StGB) and the Concept of a Serious Act of Violent Subversion: The German Federal Court of Justice (Bundesgerichtshof), Judgment of $8^{\text {th }}$ May 2014-3 StR 243/13, 18 GERMAN L.J. 631, 631 (2017).
} 
the StGB remains insufficient when it comes to prosecuting crimes committed outside of Germany. The main reason for this is due to the missing relationship between the crime and a domestic reference. A domestic reference exists if the crime was committed on national grounds or if the victim or perpetrator are citizens of the country. When examining terrorist acts fully, neither is the case. Besides, the rules of the Rome Statute do not apply to German Law as they are not so-called "self-executing norms." ${ }^{10}$ Article 2(3) of the U.N. Charter states the principle of equal sovereignty amongst the Member States, thereby making it impossible to interfere with other countries' jurisdictions. The Rome Statute underlies the principle of complementarity. Pursuant to Article 17 of the Rome Statute, a national jurisdiction takes precedence only if national courts fail to prosecute. Therefore, effective national prosecution of crimes committed in Iraq and Syria ${ }^{11}$ would have been impossible without legal regulation. The German government reacted to such obstacles by introducing the Code of Crimes against International Law (VStGB). The Code came into force on June 30, 2002, and applies to crimes violating international humanitarian law regardless of the domestic reference, as set out in $\$ 1$ VStGB. This is called the Principle of Global Law. ${ }^{12}$ It is the basis of all investigations in conjunction with the VStGB, which enables German criminal prosecutors to probe crimes committed abroad and where no German citizens were involved. ${ }^{13}$ The criminal offenses covered by the VStGB include-beyond the scope of the Rome Statute-the area of core crimes that can be regarded as protected under customary international law. ${ }^{14}$ The German Federal Prosecutor's Office currently focuses on so-called Syrian returnees, and, in particular, persons who have joined the Islamic State or other armed groups in Syria and are suspected of having committed war crimes. ${ }^{15}$ This is the context in which the present Federal Court of Justice's decision was issued. ${ }^{16}$ Alongside the predominantly person-related investigations, Germany attempted to implement legal action against those crimes using structural investigations (Strukturverfahren). To commence such proceedings, the Attorney General would initiate broad-based investigations without specific suspects by collecting evidence available in Germany and facilitating future proceedings in or outside Germany. Cases involving the desecration of corpses could previously only be prosecuted pursuant to specific sections, such as $₫ 168$ StGB-disturbance of the peace of the dead ${ }^{17}$ — which provides a maximum term of imprisonment of three years or a fine. This, however, does not sufficiently punish the perpetrators who desecrate corpses in conflicts. In addition, the VStGB had, pending this decision, only covered the protection of the living.

\section{Facts of the Case}

Aria L. (“L."), born in 1995, was raised in Offenbach, Germany by his Iranian parents who were Shiites but who never followed a strict religious education. $L$. ran up a lengthy criminal record in his teen years. He started radicalizing himself early by, inter alia, reading the mission literature of the Sunnites. By 2013 at the latest, he declared himself to be Islamist-Salafist-Orientated and started spreading Islamist beliefs through the so-called "Da'War" profession. ${ }^{18}$ In 2011, the

\footnotetext{
${ }^{10}$ See Kai Ambos, Deceased Persons as Protected Persons Within the Meaning of International Humanitarian Law, 16 J. INT'L CRIM. JUST. 1105, 1116 (2018).

${ }^{11}$ See QઐA: First Cracks to Impunity in Syria, Iraq, Human Rights Watch (Oct. 20, 2016, 12:01 AM), https://www.hrw. org/news/2016/10/20/qa-first-cracks-impunity-syria-iraq.

${ }^{12} I d$.

${ }^{13}$ See Jörg Diehl, Interview: BKA-Ermittler gegen Kriegsverbrecher "Aufnahmen von Enthauptungen vergessen Sie nicht", BuNDESKRIMINALAMT (June 22, 2017), https://www.bka.de/DE/Presse/Interviews/2017/170623_InterviewZornSpiegelOnline.html.

${ }^{14}$ Sascha R. LÜder \& Thomas Vormbaum, Materialien zum VÖlKerstrafgesetzbuch 39 (2002).

${ }^{15}$ See Stefanie Bock \& Nicolai Bülte, Die Strafbarkeit von Leichenschändungen nach dem VStGB und die Herausforderungen einer völkerrechtlichen Auslegung, 3 HRRS 100 (2018).

${ }^{16}$ Judgment of July 27, 2017.

${ }^{17}$ See STGB.

${ }^{18}$ Judgment of July 27, 2017.
} 
protests against the Assad-Militia resulted in an armed conflict between the military and rioterswhich is still ongoing at the time of this Article. To date, there have been around 100,000 nongovernment and 200,000 government and paramilitary combatants involved. ${ }^{19}$

In 2014, L. went to Syria to participate in the "Holy War," which, in particular, was against the Bashar al-Assad regime. Initially, he found accommodation at $V .{ }^{20}{ }^{20}$ quarters where he learned how to handle weapons. Soon after, V.'s troops attacked a Syrian Military checkpoint where they captured at least two soldiers, both of whom they beheaded. The heads were then skewered onto metal poles and placed in front of a school where the accused took pictures of himself with them. ${ }^{21}$ $V$. then uploaded these detailed, close-up pictures onto the social media platform Facebook. ${ }^{22}$ Upon his return to Germany, L. was arrested.

Preliminary proceedings pursuant to $\$ 8(1)$ no. 1 VStGB, punishing the killing of a person who is protected under International humanitarian law, and investigations concerning the participation in a terrorist organization were stayed by the Federal Prosecutor-who has the responsibility to initiate proceedings if international humanitarian law is violated. However, because the Federal Prosecutor's Office deemed $L$.'s actions to be an infringement of $\$ 8(1)$ no. 9 VStGB, the corresponding charges were subsequently pressed, and the case was heard before the OLG Frankfurt am Main.

\section{The Decision}

The OLG Frankfurt am Main dealt with $L$. 's case. ${ }^{23}$ The judges considered $L$. to be an adult due to the extent of his crimes rather than an adolescent, which would have made juvenile law applicable in accordance with $\$ 105(1)$ Youth Courts Law (JGG).$^{24}$ German law imposes a minimum sentence of one-year imprisonment for crimes pursuant to $\$ 8(1)$ no. 9 VStGB. L. was subsequently sentenced to a two-year term of imprisonment with no possibility of parole.

The defendant appealed the decision on the grounds of factual claims. In its judgment ${ }^{25}$ the BGH upheld the OLG's conviction and sentence, stating that it could not ascertain any error of law at the expense of the accused. By virtue of this decision, the desecration of corpses is now considered a war crime punishable under German law pursuant to $\$ 8(1)$ no. 9 VStGB, the equivalent to Article 8 (2)(b)(xxi) for an international armed conflict and Article 8(3)(ii) of the Rome Statute for a non-international conflict. In its decision, the BGH adopted a rather broad understanding of $\$ 8(1)$ no. 9 VStGB.$^{26}$ Additionally, parts of the literature ${ }^{27}$ sought a different approach to convicting the perpetrator, claiming that the $\mathrm{BGH}$ decision did not provide an effective solution.

\section{Legal Reasoning}

As mentioned above, Germany has accepted the responsibility of contributing, at a national level, to the fight against the impunity of international crimes. The enactment of the VStGB ensures that Germany is able to prosecute crimes falling under the jurisdiction of the ICC and adapt German criminal law to the provisions of the Rome Statute. The four core crimes-genocide, crimes

\footnotetext{
${ }^{19}$ Ian Black, Wake-up Call on Syrian Army Weakness Prompted Russian Intervention, THE GUARDIAN (Oct. 1, 2015), https://www.theguardian.com/world/2015/oct/01/syrian-military-weakness-russian-intervention.

${ }^{20}$ Remains anonymous.

${ }^{21}$ Judgment of July 27, 2017 at para. 5.

${ }^{22} I d$. at para. 7.

${ }^{23} \mathrm{See}$ Oberlandesgericht Frankfurt am Main [OLG Frankfurt] [Higher Regional Court of Frankfurt am Main], (July 12, 2016), BECK-RECHTSPRECHUNG [BeckRs] 19047, 2016 (Ger.).

${ }^{24}$ See Jugendgerichtsgesetz [JGG] [Youth Courts Act], June 19, 2019, BGBL I at 840.

${ }^{25}$ Judgment of July 27, 2017.

${ }^{26}$ See 8 Wolfgang Joecks \& Klaus Miebach, Münchener Kommentar zum Strafgesetzbuch $\$ 8$ (Robin Geiß \& Andreas Zimmermann eds., 3d ed. 2017) [hereinafter MüKo-VStGB].

${ }^{27}$ E.g., Lars Berster, Leichenschändung als Kriegsverbrechen, 5 ZIS 264 (2017); Ambos, supra note 10; Bock \& Bülte, supra note 15 .
} 
against humanity, war crimes, and crimes of aggression-largely mirror the crimes defined in the Rome Statute. The decision examined here is based on $\$ 8(1)$ no. 9 VStGB, which is the equivalent to Article 8(2)(b)(xxi) and (c)(ii) of the Rome Statute on war crimes.

This Article focuses on a key element: The protected person under international humanitarian law. As already indicated above, the BGH construed the term "person" in a broad manner using different methods of interpretation in the judgment. Of the several possible methods, the BGH focused on the interpretation of the wording and teleological interpretation using previous jurisprudence from international law, as well as considering a footnote in the ICC's Elements of Crimes. ${ }^{28}$

This Article examines all the requirements for the commission of an offense pursuant to $\$ 8(1)$ no. 9 VStGB: The existence of an international or non-international armed conflict, the degradation or humiliation of a person in a severe manner, and a protected person pursuant to International humanitarian law as defined in $₫ 8(6)$ VStGB.

\section{Non-International Armed Conflict}

The existence of an armed conflict is the first requirement stipulated in $₫ 8(1)$ no. 9 VStGB. German law comprises both international and non-international conflicts and does not differentiate between an armed conflict's international or non-international character regarding any legal consequences. ${ }^{29}$ The differentiation solely becomes relevant concerning the definition of a "protected person" according to humanitarian law. ${ }^{30}$ At the time the crime was committed, the dispute that was taking place between the Syrian government's army and opposition fighters did not involve an armed conflict among states. ${ }^{31}$ The dispute involved intrastate armed forces against organized armed groups and was of a certain duration and intensity. ${ }^{32}$ Therefore, the present situation of the case can be classified as a "noninternational armed conflict." ${ }^{33}$ Furthermore, the question as to whether the Syrian Civil War developed into an international conflict with the intervention of foreign forces is insignificant in this case because the situation was characterized as non-international, at least in the spring of 2014, when Aria L.'s crime was committed. ${ }^{34}$

\section{Protected Person Under International Humanitarian Law}

Pursuant to $\$ 8(1)$ No. 9 VStGB, the person concerned must be a person protected under international humanitarian law. The legal definition of this term can be found in $\$ 8(6) \mathrm{VStGB} .{ }^{35}$ The BGH based its argument on no. 2 of the aforementioned subsection pertaining to a non-international armed conflict. ${ }^{36}$ Specifically, such persons who are taking no active part in the hostilities and who are under the power of the adverse party must be considered protected under international humanitarian law in connection with a non-international armed conflict. ${ }^{37}$ These include, inter alia, enemy combatants-members of the

\footnotetext{
${ }^{28}$ The Elements of Crimes constitute an addition to the Rome Statute and were adopted at the 2010 Review Conference. They shall assist the ICC in the interpretation and application of the core crimes.

${ }^{29}$ The German legislature followed the verdict of the ICTY in the Tadič case and consciously opted against the two-box approach favored by the Rome Statute. Cf. Christoph Safferling, Report-German Public Law Legislation-2001/2002: Das Völkerstrafgesetzbuch, in 1 The ANNUAL FOR GERMAN AND European LAW, 366, 366-80 (2003).

${ }^{30} \mathrm{Cf}$. VÖlKerstrafgesetzbuch [VStGB] [International Criminal Code], $₫ 8(6)$ [hereinafter VStGB].

${ }^{31}$ Judgment of July 27, 2017 at para. 12.

${ }^{32}$ Such as "Free Syrian Army," "Jabhat al-Nusra," and the "Islamic State in Iraq and Syria." See also Judgment of July 27, 2017 at para. 12.

${ }^{33}$ Judgment of July 27, 2017 at para. 12; see also MüKo-VStGB, supra note 26, at paras. 96, 98.

${ }^{34}$ Judgment of July 27, 2017 at para. 12.

${ }^{35} \mathrm{VSTGB}, \S 8(6)$.

${ }^{36}$ Judgment of July 27, 2017 at para. 13.

${ }^{37}$ See VSTGB, $\$ 8(6)$ no. (2).
} 
armed forces-who are in an hors de combat condition. ${ }^{38}$ Hors de combat is a term known under customary international law ${ }^{39}$ meaning that a combatant is incapacitated and can no longer take part in the conflict. ${ }^{40}$ With regard to this matter, the $\mathrm{BGH}$, irrespective of the sole commentary on the VStGB, drew upon a similar regulation pursuant to Article $8(2)(c)$ of the Rome Statute. ${ }^{41}$ In the present case, Jihadist enemy fighters captured and disarmed the two soldiers who belonged to the Syrian government forces. Therefore, the soldiers were in an hors de combat state. It is, however, generally an unresolved question as to whether the scope of protection of $₫ 8(1)$ no. 9 VStGB encompasses persons after they have been killed.

\section{Common and Legal Understanding of the Term "Person" in a German Context}

The scope of protection of $\$ 8(1)$ no. 9 VStGB covers "persons" to be protected under international humanitarian law. The BGH assumed that the section refers "equally to living and deceased people." ${ }^{2}$ While other countries' laws have been developed by case law, Germany's law is codified. As the statutes cannot comprise all potential variants, the jurisprudence must interpret the wording of the law. Many interpretive methods have distilled through the courts' various judgments over past decades while certain rules have to be followed. The BGH is also obliged to follow these rules when interpreting the norm at hand. In order to understand the interpretation methods in their entirety, they will be briefly explained below.

The BGH based its arguments on the wording of the law-the meaning behind the exact wording of the statute. ${ }^{43}$ A semantic analysis, as well as an analysis of the syntax, can provide arguments for this interpretation method. The point of departure for the interpretation is the linguistics of the law, and only when this interpretation is insufficient will legal literature and the common language be consulted. A further method used is the teleological interpretation, which aims to ascertain the ratio legis - in other words the reason or purpose for making a law-of the law. ${ }^{44}$ It shall be elaborated upon whether a legal regulation applies to circumstances of a case regarding its intent and purpose. The meaning of the law and the scope of the legislation is determined through teleological interpretation, while the ratio legis should not be modified. ${ }^{45}$

On the one hand, the use of the term "person" in common and legal language must be examined. It is questionable whether common language includes only the living under the term "person." If the deceased are meant to be included, the adjective "dead" is always utilized. The BGH grounded parts of its argument on the interpretation of "person" as defined by the German Duden. ${ }^{46}$ The Duden portrays the "person" as a terminology that is used for an individual human in his function as a carrier of a consistent and conscious ego. ${ }^{47} \mathrm{In}$ order

\footnotetext{
${ }^{38}$ Judgment of July 27, 2017 at para. 13. For more detailed information on the term hors de combat, see MüKo-VStGB, supra note 27, at para. 90.

${ }^{39}$ See Protocol Additions to the Geneva Conventions of 12 August 1949, and Relating to the Protection of Victims of International Armed Conflicts art. 41, June 8, 1977, 1125 U.N.T.S. 3 (regarding international armed conflicts) [hereinafter Geneva Convention Protocol I]; Geneva Convention Relative to the Treatment of Prisoners of War, Aug. 12, 1949, 75 U.N.T.S. 135 (regarding non-international armed conflicts); Protocol Additional to the Geneva Conventions of 12 August 1949, and Relating to the Protection of Victims of Non-International Armed Conflicts (Protocol II) art. 4, June 8, 1977, 1125 U.N.T.S. 609 (regarding non-international armed conflicts).

${ }^{40}$ See MüKo-VStGB, supra note 27, at para. 96.

${ }^{41}$ Judgment of July 27, 2017 at para. 13; Gerhard Werle \& Florian JeßBERGER, VÖlKerstrafrecht 1236, 1238 (4th ed. 2018).

${ }^{42}$ Bock \& Bülte, supra note 15; Judgment of July 27, 2017 at para. 28.

${ }^{43}$ See Olaf Muthorst, Auslegung: Eine Einführung, 10 JuristisChe ArbeitsblätTER [JA] 721, 725 (2013).

${ }^{44}$ See 8 Franz JÜrgen Säcker, Münchener Kommentar zum Bürgerlichen Gesetzbuch para. 143 (8th ed. 2018).

${ }^{45} I d$.

${ }^{46}$ The German Duden is a respected dictionary comprised of German words, their meanings, and further possibilities of their usage.

${ }^{47}$ See Person, German Duden.
} 
to have a conscious ego, the human itself has to be alive to be aware of such. This leads to the conclusion that "person" shall only be applied to living human beings.

On the other hand, "person" is a mere description of a human being with regard to the exterior physical characteristics. ${ }^{48}$ If this interpretation is followed, deceased persons are also included within the term "person," as an exterior physical characterization is possible regardless of the person's condition. "Person" can be replaced by the synonyms "creature," "head," "human," "individual," "personality," or "element," depending on the context of the sentence. Neither of these arguments is compelling enough on its own to eliminate the other, leading to the conclusion that denying a broad understanding of the term "person" does not seem possible. Thus, a final decision cannot be made with linguistic scrutiny alone, as the context and the intention behind the usage of the term "person" must also be considered.

By using international humanitarian law for the interpretation, it can be found that the Geneva Law differentiates between "persons" and "dead" by explicitly using terms such as "wounded" or "dead." ${ }^{4}$ The relevant guidelines of the Geneva Convention-Article 3 Geneva Convention (1949) and Article 4 II Additional Protocol I (1977) of the Geneva Conventions 1949-do not extend the scope of protection onto deceased persons. Even the International Committee of the Red Cross's Study on Customary International Humanitarian Law does not include the deceased-they are only protected from ransacking and mutilation. Furthermore, the Elements of Crimes stipulates the coverage of deceased persons solely in a footnote. ${ }^{50}$ However, it should assist the Court in the interpretation. ${ }^{51}$ Nevertheless, the fact that the protection of deceased persons was demoted to a footnote illustrates that the signatories could not agree upon the inclusion of the word deceased. ${ }^{52}$ This further indicates that it is questionable to assume that deceased persons should be included in the scope of protection.

As mentioned above, the BGH assumed that the term "person" refers to "equally living and deceased people," stating that this would correspond to the language used in the StGB. ${ }^{53}$ The BGH based its main argument on $\$ 168(1)$ StGB, where the legislator chose to clarify the term as "deceased person" by adding the relevant adjective. ${ }^{54}$ However, the StGB uses the phrase "person" only if it is referring to living humans. ${ }^{55}$ There is no possibility of committing a murder ${ }^{56}$ or an assault ${ }^{57}$ on a deceased person. The status of living is a basic prerequisite for committing the crime. Therefore, if a statute protects deceased persons, it is explicitly mentioned, as can be seen in $\$ 168$ StGB. ${ }^{58}$

\section{Previous International Law Jurisdiction}

International tribunals have previously passed judgments concerning the punishment for the desecration of corpses under customary international law. Upon further scrutiny, the integration of the offense into customary international law appears somewhat questionable.

A number of the judgments from international tribunals-namely the International Criminal Tribunal for the former Yugoslavia (ICTY) and the International Criminal

\footnotetext{
${ }^{48} I d$.

${ }^{49}$ See Geneva Convention for the Amelioration of the Condition of the Wounded and Sick in Armed Forced in the Field art. 15, Aug. 12, 1949, 75 U.N.T.S. 31; Geneva Convention Protocol I, art. 34.

${ }^{50}$ See Rome Statute to the International Criminal Court art. 9, July 17, 1998, 2187 U.N.T.S. 90.

${ }^{51}$ Ambos, supra note 10, at para. 1116.

${ }^{52} I d$.

${ }^{53}$ Judgment of July 27, 2017 at para. 28.

${ }^{54} I d$.

${ }^{55}$ Bock \& Bülte, supra note 15.

${ }^{56}$ See STGB, $\$ 211$.

${ }^{57}$ See STGB, $\$ 223$.

${ }^{58}$ Bock \& Bülte, supra note 15, para. 100, 101; Ambos, supra note 10, at para. 1105, 1110.
} 
Tribunal of Rwanda (ICTR)—demonstrate how they dealt with the desecration of corpses. ${ }^{59}$ The desecration of corpses was already considered punishable under customary international law, ${ }^{60}$ which can be clearly examined from the ICTY judgment in Brdanin. In this judgment, the ICTY ruled that undignified treatment, mutilation, burials in mass graves, and reburials of casualties must be considered humiliating and degrading. ${ }^{61}$ The defendant there made two arguments against this holding: First, that the act itself was not considered a war crime but rather a crime against humanity pursuant to Article 5(h) ICTY Statute and hence cannot be compared; second, that the trial chamber itself explicitly labeled the aforementioned act as a "humiliating gesture." Even though the desecration of corpses as such is not codified, it can be portrayed as a war crime or a crime against humanity pending the decision of the chamber. ${ }^{62}$ Yet it is insignificant at this point whether the offense committed should be classified as a war crime or a crime against humanity. The salient point is that this decision reveals that deceased persons are also encompassed within the scope of protection; thus, the desecration of corpses is punishable under customary international law in the context of armed conflicts.

Additionally, the BGH examined a further example: A judgment of the ICTR that punished the insertion of a bottle into the vagina of a female corpse. ${ }^{63}$ This decision correlates with the aforementioned judgment of the ICTY.

\section{Intention of the Legislature and Rome Statute}

As mentioned above, one further method of interpretation to be taken into consideration is the intention of the legislator. By enacting the VStGB, the penal provisions of the Rome Statute were to be implemented so that the German judiciary would, by itself, perpetually be in a position to prosecute crimes that fall within the competence of the ICC. ${ }^{64}$ Furthermore, the legislator perceived an essential step towards implementing established customary international law into national law by aligning the VStGB with the Rome Statute. ${ }^{65}$ At this point, the $\mathrm{BGH}$ elucidates that the legislator has, in essence, considered established customary international law as being codified in the Rome Statute. This is a particularly intricate point as German law is rather hostile towards finding a criminal prohibition based upon custom. Article $103(2) \mathrm{GG}^{66}$ is generally construed as requesting a written norm when it comes to prosecuting crimes.

Therefore, $\$ 8(1)$ no. 9 VStGB is thought to be based on Articles $8(2)(b)$ (xxi) and (c)(ii) of the Rome Statute. ${ }^{67}$ This Article stipulates that the degradation and humiliation of a person protected under international humanitarian law in connection with an international or non-international armed conflict is considered to be a war crime. ${ }^{68}$ The provisions of Article 8 of the Rome Statute should, by virtue of Article 21(1)(a), be legally interpreted with regard to the so-called Elements of Crime, which are an addition to the Rome Statute and were adopted at the 2010 Review Conference. Article 9 of the Rome Statute enables the ICC to apply the Elements of Crimes when interpreting the core crimes. Furthermore, Article 21 establishes a hierarchy of applicable law and

\footnotetext{
${ }^{59}$ See Prosecutor v. Brđanin, Case No. IT-99-36-T, Judgement, 2 (Int'l Crim. Trib. For the Former Yugoslavia Sept. 1, 2004); Prosecutor v. Bagosora, Case No. ICTR-98-41-T, Judgment and Sentence, 1 (Dec. 18, 2008); see also Prosecutor v. Bagosora, Case No. ICTR-98-41-A, Appeals Chamber Judgment (Dec. 14, 2011).

${ }^{60}$ See Judgment of July 27, 2017 at para. 28.

${ }^{61}$ Prosecutor v. Brđanin, Case No. IT-99-36-T, Judgment, 1019 (Int'l Crim. Trib. for the Former Yugoslavia Sept. 1, 2004).

${ }^{62}$ Berster, supra note 28 , at 267.

${ }^{63}$ Prosecutor v. Bagosora, ICTR-98-41-A, Appeals Chamber Judgment, 729 (Dec. 12, 2011).

${ }^{64}$ Judgment of July 27, 2017 at para. 19.

${ }^{65} I d$.

${ }^{66}$ GRUNDGESETZ [GG] [BASIC LAW], art. 103(2), (“An act may be punished only if it was defined by law as a criminal offence before the act was committed.").

${ }^{67}$ See Rome Statute to the International Criminal Court, arts. 8(2)(b)(xxi), 8(2)(c)(ii), July 17, 1998, 2187 U.N.T.S. 90.

${ }^{68} \mathrm{Judgment}$ of July 27, 2017 at para. 19.
} 
reflects compromises reached in negotiations. ${ }^{69}$ The most important issue at risk while drafting Article 21 was how much discretion should be given to ICC judges with regard to the conflicting requirements of the principle of legality, on the one hand, and the inevitability of gaps in an emerging legal system, on the other hand. ${ }^{70}$ In summary, Article 21 represents a compromise between these two demands: If all sources fail, the Court must refer to general principles arising from national law. ${ }^{71}$ This must also apply to national courts when they interpret the law. With regard to the elements relating to the relevant Articles 8(2)(b)(xxi) and (c)(ii) of the Rome Statute, it has been elaborated upon in a footnote that the regulations also refer to deceased persons. ${ }^{72}$

Nonetheless, the use of an explanatory footnote as a binding rule of customary international law has been criticized. ${ }^{73}$ First, it is argued that a footnote cannot constitute customary international law because the Elements of Crime are merely a non-binding aid to interpretation. ${ }^{74}$ Second, the fact that it was not codified directly in the Elements of Crime questions whether the ICC member states wanted the deceased to be recognized as persons under these stipulations. It has been claimed that including certain elements in footnotes was only an apparent solution for disagreements that could not be properly settled. ${ }^{75}$

Notwithstanding, it is a fact that the section mentioned above served as a template for the equivalent $\$ 8(1)$ no. $9 \mathrm{VStGB},{ }^{76}$ and consequently, the deceased should be protected under this section as well. ${ }^{77}$

\section{Prohibition of Analogy (Lex Stricta)}

While the precise wording sets the borders of the interpretation methods, because an interpretation cannot expand beyond the law's purpose, ${ }^{78}$ the courts must pay attention to the prohibition of analogy and retroactive effect. The prohibition of analogy proscribes the application of the elements of the actus reus and the aggravating factors within a statute when it is not appropriate for the punished act. ${ }^{79}$ Both prohibitions are firmly entrenched in criminal law. Even though the section in question is meant to regulate an exterritorial matter, the prohibition of analogy remains applicable because the VStGB is a German statutory code. In particular, while trying to extend the term "person," the BGH also faced those regulatory borders. It stated that the gravely humiliating or degrading treatment of a person who is to be protected under international humanitarian law also incorporates deceased persons ${ }^{80}$ and does not, therefore, constitute an infringement of the prohibition of analogy. ${ }^{81}$ Generally, the term "person" is coterminous with the term "human being" in common parlance. ${ }^{82}$ Furthermore, this term equally encompasses living, as well as deceased, humans, and the accompaniment of the adjective clarifies whether the respective human is deceased or alive. ${ }^{83}$ The BGH refers to the aforementioned example from the StGB and thereby emphasizes linguistic usage.

\footnotetext{
${ }^{69}$ See Otto Triffterer \& Kai Ambos, The Rome Statute of the International Criminal Court art. 21, para. 1 (3d ed. 2015).

${ }^{70} I d$. at para. 2.

${ }^{71} I d$.

${ }^{72}$ See MüKo-VStGB, supra note 27, at para. 204; see also WERLE \& JEßBERGER, supra note 4141, at paras. $1236,1238$.

${ }^{73}$ Ambos, supra note 10 , at para. 1116 .

${ }^{74}$ See Christoph SAFFerling, Internationales Strafrecht $\$ 4$, para. 87 (2012).

${ }^{75}$ See Ambos, supra note 10, at para. 1116; Berster, supra note 28, at 266.

${ }^{76}$ Gesetzesentwurf [Bill], Deutscher Bundestag: DruCKSACHEN [BT] 14/8524, 28.

${ }^{77}$ See MüKo-VStGB, supra note 27, at para. 204; see also Werle \& JEßBERGER, supra note 42, at para. 1238.

${ }^{78} \mathrm{Id}$.

${ }^{79}$ See Adolf SchÖNKe \& Horst Schröder, Strafgesetzbuch $₫ 1$, para. 25 (30th ed. 2019).

${ }^{80} \mathrm{Judgment}$ of July 27, 2017 at para. 16.

${ }^{81} \mathrm{Id}$. at para. 28.

${ }^{82}$ See Id. at para. 28; see also Person, German Duden.

${ }^{83} \mathrm{Judgment}$ of July 27, 2017 at para. 28.
} 
From a constitutional perspective, it is questionable whether the interpretation of the BGH is compatible with the constitutionally established prohibition of analogy.

Other voices in literature, however, claim that a corpse cannot be the object of protection pursuant to the wording of $\$ 8(1)$ no. 9 VStGB. According to the exact wording of the aforementioned section, a "person" is protected and is not a "deceased person." ${ }^{4}$ The reasons mentioned provide that a person denotes a living human individual. This can be proven by the usage of this term throughout the StGB, where it always concerns a living person. For instance, an indubitably living person must be the victim of bodily harm pursuant to $₫ 223$ StGB. ${ }^{85}$ Because $₫ 168(1)$ StGB also explicitly refers to a deceased person, it appears that the term "person" without any further linguistic modification shall relate only to living individuals. ${ }^{86}$ Therefore, the application of this section to cases regarding deceased persons would constitute a breach of the prohibition of criminalization by analogy. ${ }^{87}$

In the case at hand, it can be noted that international law provides for post-mortem protection of personality (postmortaler Persönlichkeitsschutz) and that the scope of $\$ 8$ VStGB shall therefore extend to deceased persons by interpreting it in conformity with international law. Contrary to the $\mathrm{BGH}$, it seems conceivable to assume an extended version of the term "person," including deceased persons, solely for $\$ 8(1)$ no. 9 VStGB. ${ }^{88}$ Section $8(1)$ no. 4 VStGB also speaks of "persons" with regard to the protection of sexual self-determination. It is, of course, indisputable that sexual self-determination cannot last beyond death. Therefore, an extension of the term "person" within this section is also disputable. This leads to the conclusion that a specific extension exists solely for $\$ 8(1)$ no. 9 VStGB. ${ }^{89}$

\section{Degradation or Humiliation of a Person in a Severe Manner}

A further requirement is that the perpetrator must treat the person concerned in a gravely humiliating or degrading manner. It is arguable whether $₫ 8(1)$ no. 9 VStGB is still applicable if the criminal act solely affects parts of a corpse.

Pursuant to Article 1(1) GG, human dignity shall be inviolable. ${ }^{90}$ This article protects every human being regardless of their social status, individual characteristics, or achievements. ${ }^{91}$ Nevertheless, several German legal literature commentators claim that the deceased are not legal subjects with regard to human dignity under Article 1(1) GG. According to the wording of this article, the subject of human dignity must be a living human.

In contrast, the BGH stated that in any case, the intent and purpose of the statute includes the protection of human dignity and the commemoration of the deceased if the action affects the victim's head. ${ }^{92}$ Thus, by taking pictures of themselves with the detached heads of the oppositional combatants skewered on metal poles, the accused treated the heads, and ergo the soldiers, in a gravely humiliating and degrading manner. ${ }^{93}$ Moreover, international jurisprudence states that the desecration of a corpse is, as a matter of fact, a "profound assault on human dignity." 94 Additionally, the guarantee of human dignity is, at least to some degree, protected beyond death,

\footnotetext{
${ }^{84}$ VSTGB, $₫ 8(1)$ no. (9).

${ }^{85} \mathrm{STGB}$.

${ }^{86}$ See Berster, supra note 28, 268; see also STGB, $₫ 168$ (1) (stipulating the desecration of graves).

${ }^{87}$ See GG, art. 103(2); STGB, $₫ 1$.

${ }^{88}$ The different extension of a term within the same statute is already known in German law, namely the different understanding of "taking away" in the STGB. See STGB, $\$ \$ 242,289$.

${ }^{89}$ See Bock \& Bülte, supra note 15.

${ }^{90} \mathrm{GG}$, art. 1(1)

${ }^{91}$ See VolKer Epping \& Christian Hillgruber, BeckOK Grundgesetz, art. 1, para. 3 (35th ed. 2017).

${ }^{92} J u d g m e n t$ of July 27, 2017 at para. 32; Bock \& Bülte, supra note 15.

${ }^{93}$ Judgment of July 27, 2017 at para. 35.

${ }^{94}$ Prosecutor v. Bagosora, Case No. ICTR-98-41-A, Appeals Chamber Judgment, para. 729 (Dec. 14, 2011).
} 
according to the German Federal Constitutional Court (Bundesverfassungsgericht).$^{95}$ For example, the insertion of a bottle into the vagina of a female corpse was declared a sexual assault constituting a serious attack on human dignity as it was driven by the intent to cause serious bodily or mental harm to the victim. ${ }^{96}$ The Chamber of the ICTR, therefore, found the accused guilty of crimes against humanity pursuant to Article 6(3) and Article 3(1)(i) of the ICTR Statute. ${ }^{97}$

The ICTR has also deemed treatment to be humiliating if a female victim is obliged to perform gymnastic exercises in front of a group of perpetrators after being oppressively stripped. ${ }^{98}$ Thus, sexual violence is not limited to physical invasion of the human body and may include acts that do not involve penetration or even physical contact. ${ }^{99}$ Such acts can be declared "inhumane" and "serious bodily or mental harm" and, therefore, punishable under Article 3(1)(i) and Article 2(2)(b) of the ICTR Statute. ${ }^{100}$ The ICTR, therefore, recognizes the actions of the accused as being crimes against humanity and genocide, even if there was no physical invasion of the victims.

The Chamber of the ICTY also declared mere expressions as sufficient to affirm a humiliating treatment. ${ }^{101}$ Thus, physical harm is not necessary to punish crimes against humanity pursuant to Article 5(1)(i) of the ICTY Statute. Furthermore, the ICTY declared that forcing captured Bosnian Muslim victims to sing Četnik songs and perform the three-fingered Serbian salute constitutes a persistent insult ${ }^{102}$ and establishes a crime against humanity. Therefore, international judgments reveal that physical maltreatment is not necessary in order to be deemed a humiliating or degrading treatment.

In the present case, it was not proven whether the accused physically harmed the deceased soldiers. It was only confirmed that he took photographs with their heads in front of a school. ${ }^{103}$ Referring to the aforementioned decisions, the treatment of the accused in terms of taking photographs of the severed heads of the two soldiers, which were detached and skewered on metal poles, can constitute an offense under $\$ 8(1)$ no. $9 \mathrm{VStGB}$, even if the perpetrator did not physically harm the soldiers.

\section{E. Conclusion of the Critical Examination}

War crimes remain a potent issue and must be prosecuted effectively. The German Federal Prosecutor's Office has had to deal with numerous situations and charges regarding war crimes committed in Syria. The department is on high alert concerning Germans who return from Syria or criminals who travel to Europe as refugees. Additionally, the department is ready to further develop the law of international crimes. Crimes connected to the humiliation and mutilation of persons involved in armed conflicts have gained significant relevance with the omnipresence and pertinence of today's social media. From a prosecutor's perspective, these cases are relatively straightforward as the digital evidence is readily available in Germany, even if the crime took place in Syria. The present case highlights the ongoing problems with prosecuting war-related crimes. Several German legal academics claim that a corpse is not covered by the scope of protection of $\$$ 8(1) no. 9 VStGB and that the desecration of corpses should not be recognized as a war crime under customary international law. Therefore, the BGH ruled that $\$ 8(1)$ no. 9 VStGB is applicable specifically in the context of the acts perpetrated in Aria L.'s case, leaving open the possibility that

\footnotetext{
${ }^{95}$ Bundesverfassungsgericht [BVerfG] [Federal Constitutional Court] Feb. 24, 1971, NeUE JURISTISCHE WOCHENSCHRIFT [NJW] 1645, 1647, 1971 (Ger.).

${ }^{96} I d$.

${ }^{97}$ Prosecutor v. Bagosora, Case No. ICTR-98-41-T, Judgment and Sentence, 2224 (Dec. 18, 2008).

${ }^{98}$ Prosecutor v. Akayesu, Case No. ICTR-96-4-T, Judgment, 688, 694 (Sept. 2, 1998).

${ }^{99} I d$.

${ }^{100} \mathrm{Id}$.

${ }^{101}$ Prosecutor v. Kvočka, Case No. ICTY 98-30/1-T, Judgment, 172 (Nov. 2, 2001).

${ }^{102}$ Prosecutor v. Brđanin, Case No. IT-99-36-T, Judgment, 1015 (Int'l Crim. Trib. For the Former Yugoslavia Sep. 1, 2004).

${ }^{103}$ Judgment of July 27, 2017 at para. 5.
} 
different factual circumstances may not fall within the prescriptive jurisdiction of $\$ 8(1)$ no. 9 VStGB. Reflecting upon the BGH's view and negating the opposing view, it can be concluded that the term of the protected person pursuant to $\$ 8(1)$ no. $9 \mathrm{VStGB}$, should be extended to encompass the deceased as well as the living. Even though the necessity to punish the desecration of corpses in international and non-international conflicts is obvious, resolving it must be in accordance with fundamental constitutional principles. 